\title{
Economics of Dairy Farm: Simulation Study
}

\author{
Nedvědová Marie ${ }^{1, *}$, Marek Jaroslav ${ }^{1}$, Pozdílková Alena $^{1}$ and Haloun Tomáš \\ ${ }^{1}$ University of Pardubice, Faculty of Electrical Engineering and Informatics, Studentská 95, Pardubice, 532 10, Czech Republic \\ ${ }^{2}$ Czech University of Life Sciences Prague, Faculty of Agrobiology, Food and Natural Resources, Department of Veterinary Sciences, \\ Prague, Czech Republic \\ ${ }^{*}$ Corresponding author. Email address: marie.nedvedova@upce.cz
}

\begin{abstract}
The aim of this paper is to estimate economic consequences of an LDA (Left displaced abomasum) treated cow. After a surgery to correct this displacement, cows had a lower average milk yield, lower reproduction characteristics, and consequently a lower number of lactation cycles, less calves, longer period between calving, compared to other cows. We will use breeding simulation with the help of a constructed function to describe the price aspects. Knowledge of analysis of diary milk-yield production, probability of survival, and ability to reproduce will be used. The Arena software will be used for the simulation. The main goal is to estimate the lifelong profit of an individual cow from a group of healthy cows and an individual cow from a group with LDA disease.
\end{abstract}

Keywords: dairy cattle production; management and breeding decision; left displacement of mallow; LDA treated cows

\section{Introduction}

Analysis of cattle breeding strategies is very difficult. The biological and economic characteristics of a cattle herd are affected by many parameters. The collection of data and their analysis is also a problem. Therefore, simulation approaches based on knowledge of the most important characteristics of the herd and including management options are increasingly used. Various models for dairy farm simulation have been formulated in connection with monitoring the financial aspects of individual dairy cows in the cowshed, see (Congleton, 1983), (Kikuhara et al., 2009). The authors of the article (Kikuhara et al., 2009) use simulation and linear programming to find the optimal proportion of milk and daily feed. The subject of simulation studies are often comparisons of different types of cow housing (indoors, outdoors), cf. (Hawkins, 2019). Some publications focus on the effects of livestock genetics on farm results, see (Kariuki, 2019).

The main goal of this paper is paper is to demonstrate a possibility of simulation software to analyze the profitability of a dairy farm with the situation of known cost production of the dairy cow.

The incomes considered in our model included 305-daily yield, income from calves, profit from the sale of cow for meat. The branching in the simulation includes the following parameters: probabilities of weaning cows during lactation, success of inseminations, time between calving, prices of milk, prices of calves, 305 daily yield, daily feed costs. In the simulation, we consider as a free parameter the maximum number of unsuccessful inseminations before the dairy cow is taken out of breeding. The issue of optimal cow replacement will be particularly preferred.

The simulation will compare two groups of cows. The group of healthy cows and the group of LDA cows. Left displaced abomasum occurs in the first days after calving. The cows after corrective surgery are at a higher risk of death, shorter lactation length and are in a higher risk of being culled before the end of lactation. Cows after surgery, also have a longer calving interval, changed milk productivity and changed reproduction parameters. This increases their overall cull risk (Joritsma et al., 2008).

The analysis of LDA on herd economy is studied in many publications (Shaver, 1997). A retrospective study which analyzed data of 9315 dairy cows was published by (Hamann at al., 2014). The incidence of LDA in this study was $1.21 \%$ and the milk loss was 1,016 $\mathrm{kg}$ of milk compare to healthy cows. In our study, we made a congeneric study of 227 Holstein cows from Agro Záhoří farm, treated in the years 2006-2015.

A control group contains an information about 13,240 lactation cycles of cows from the same herd (Haloun et al., 2016). The usual

C 2020 The Authors. This article is an open access article distributed under the terms and conditions of the Creative Commons Attribution (CC BY-NC-ND) license (https://creativecommons.org/licenses/by-nc-nd/4.0/). 
incidence of LDA is approximately $3 \%$ per lactation. The disease most often occurs between the 2 nd and 3 rd week after calving - in 70 percent within 1 month, in 90 percent within 6 weeks.

In the simulation, we will assume that the date of occurrence of the disease has lognormal distribution with parameters $\mu=2.398$, $\sigma=0.367$, for $1 \leq x \leq 80$. By simulation, we will model the expected incomes and costs per dairy cow in both groups of cows.

The breeder decides on the basis of the quantity of milk in the current cycle and the health status of the dairy cow, whether the dairy cow will be left in breeding or replaced by a calved heifer. The efficiency of the previous lactation contributes to the decision whether to withdraw the cow or not. This information also leads to a decision if the dairy cow will be inseminated or not. At higher lactations, reproductive parameters deteriorate. The breeding decision determines the maximum number of inseminations before the cow is removed from breeding. Unsuccessful insemination brings a longer interval and thus increased feed costs. In the group of surgically corrected cows, losses occur due to a decrease in milk, longer lactation, premature weaning, costs of higher mortality, fewer subsequent lactations (and thus higher average acquisition costs for lactation), extended interval before further calving, and of course LDA surgery costs. The setting of exclusion parameters is necessary when implementing selection programs. The results of our analysis can be potentially used as a guidance for decision about the fate of cows after LDA surgery.

If a cow is healthy it can be inseminated approx. 50 days after parturition. The time between parturition and pregnancy is called days open. The time between calving is called calving interval. Based on the milk productivity the recommended calving interval is between 365 - 400 days. Another reproductive parameter is Service per pregnancy. Service per pregnancy for all cows measures the conception rate for all services in the herd for pregnant and open cows and is calculated by dividing the total number of services by the number of pregnant cows. If we include only services per pregnant cow into the equation, we receive service per pregnancy for pregnant cows. In this case a value lower than 2.0 is considered as a good result (Louda, 2008). Another reproductive parameter is 1st service conception rate, which is the conception rate 8 weeks after insemination, and considers all services, natality and numbers of calves per 100 cows. This is considered by some authors as a real actual parameter of reproduction for given herd. (Louda, 2008).

The usual length of gravidity of dairy cow is 285 days, the normal lactation is 305 days. The average lactation length is 360 days. If a cow conceives later, the cost of diet is somewhat compensated by a smaller milk production per day (approx. $20 \mathrm{~kg}$ ) if the lactation curve continues from 305th to 450th day.

\section{Basic ideas of cattle breeding simulation}

In the following sub-chapters, we will present parameters, which are essential for the life of the cow and most affect the financial results of breeding. The results of the simulation study will be presented in Chapter 3.

For simulation the following parameters will be used: standardized 305-day milk production, parameters of reproduction-service per pregnancy for all cows, days open, calving interval and culling parameters specific for lactation numbers. The market prices of milk, meat and calves will be also included in the model. Financial criteria will be used for evaluation of results of cows after LDA surgery. The results of the control group (group 1) and the group after surgery (group 2) will be evaluated based on the financial results. The simulation of lifelong productivity will enable us to compare profitability of both groups of cows.

\subsection{Pilot characteristics influencing managerial decisions of cattle breeders}

In successful breeds with quality breeding and veterinary care, the average culling is around 20 to 30 percent. The most common health reasons for weaning a dairy cow are the so-called production diseases - mastitis, limb diseases and reproductive problems. However, LDA is also included in this group of diseases. The decision to exclude a dairy cow and not allow the cow to inseminate is made by the breeder:

a) Based on medical condition immediately after calving.

b) On the 50th - 60th day after calving, when the first insemination takes place (after another 30 days, it is known whether the insemination was successful).

c) Around the 80th - 90th day after calving, a decision is made again which (unsuccessfully inseminated) dairy cows with small milk will no longer be allowed to further reproduce.

In the numerical study, we will assume that group a) has a share of $1 / 10$ of the lactation on a given lactation (see Table 3). Group b) will consider the same share of cow brackage in the herd. The size of group c) will be determined as 8/10 of the total brackage of the cows. The proportions for the brackage of groups a), b) and c) are important input data for the simulation. The total brackage depends on the current demand for meat and the price of meat, or on the current price of the feed. The health status of dairy cows at higher lactations and deterioration of reproductive parameters lead to higher culling of these dairy cows.

The data reserved for our research comes from the cowshed in Záhorí. The sources of the following tables come from the archive and calculations of the authors of this article. The following tables 1 and 2 show basic characteristics. Tab. 1 shows the sample averages and sample standard deviations of the total 305-day milk yields per individual lactation in group 1 and group 2. Averages and standard deviations of 305-day yield for all cows are given in Tab. 2. Tab. 2 collects the reproductive characteristics of dairy cows in both groups on different lactations. There is a noticeable deterioration of the insemination index at higher lactations. Table 3 contains information on the culling of dairy cows from the herd as well as the culling of cows after surgery. In this table, in the last column, we see the total shortening on individual lactations.

As can be seen, a range of feature values in the group of healthy and dairy cows after surgery are different. As for the insemination index, the situation is very similar, but it differs depending on which lactation cycle was used. On the other hand, however, survival probabilities ordinarily have very low values in group of cows which have undergone the surgery. In dairy cows after surgery, lactation and milk yield are reduced, culling of cows is higher and also the interval between calves is extended. Some differences in different lactations were not always statistically significant. 
Table 1. The characteristics of 305-dairy yields.

\begin{tabular}{ccrr}
\hline Group & Lactation & Average $[\mathrm{kg}]$ & Standard deviation $[\mathrm{kg}]$ \\
\hline 1 & 1 & 9,969 & 2,380 \\
1 & 2 & 10,119 & 1,789 \\
1 & 3 & 11,808 & 2,064 \\
1 & 4 & 11,918 & 2,601 \\
1 & $>4$ & 12,170 & 2,612 \\
2 & 1 & 9,551 & 1,461 \\
2 & 2 & 9,629 & 1,553 \\
2 & 3 & 10,592 & 1,564 \\
2 & 4 & 10,139 & 2,381 \\
2 & $>4$ & 12,581 & 2,510 \\
\hline
\end{tabular}

Source own.

Table 2. The reproductive characteristics of 305-dairy yields.

\begin{tabular}{ccrr}
\hline Group & Lactation & Percentage of pregnant & Insemination index \\
\hline 1 & 1 & 86.8 & 1.862 \\
1 & 2 & 86.7 & 2.352 \\
1 & 3 & 76.6 & 2.301 \\
1 & 4 & 75.2 & 2.283 \\
1 & $>4$ & 76.7 & 2.065 \\
2 & 1 & 86.8 & 2.100 \\
2 & 2 & 86.8 & 2.900 \\
2 & 3 & 86.8 & 2.630 \\
2 & 4 & 86.8 & 2.200 \\
2 & $>4$ & 86.8 & 2.330 \\
\hline
\end{tabular}

Source own.

\begin{tabular}{ccrr} 
Table 3. The probability of survival. \\
\hline Group & Lactation & $\begin{array}{r}\text { Probability of } \\
\text { non-completion of } \\
\text { lactation [\%] }\end{array}$ & $\begin{array}{r}\text { Probability of not } \\
\text { progressing to the } \\
\text { next lactation [\%] }\end{array}$ \\
\hline 1 & 1 & 9.50 & 24.79 \\
1 & 2 & 11.34 & 43.01 \\
1 & 3 & 13.83 & 51.10 \\
1 & 4 & 16.38 & 53.62 \\
1 & $>4$ & 16.36 & 60.22 \\
2 & 1 & 19.35 & 41.94 \\
2 & 2 & 28.57 & 57.14 \\
2 & 3 & 38.00 & 62.00 \\
2 & 4 & 26.32 & 78.95 \\
2 & $>4$ & 50.00 & 60.00 \\
\hline
\end{tabular}

Source own.

Table 4. The price characteristics.

\begin{tabular}{rrrr}
\hline Milk $[\mathrm{CZK} / \mathrm{kg}]$ & Meat $[\mathrm{CZK} / \mathrm{kg}]$ & Calve $[\mathrm{CZK} / \mathrm{pc}]$ & Daily feed $[\mathrm{CZK} / \mathrm{pc}]$ \\
\hline 8.57 & 30.74 & 3,000 & 155
\end{tabular}

Source own.

\subsection{Enumeration of mechanisms for simulation}

There are several key parameters affecting breeding profitability. While daily yield, reproductive characteristics and survival probabilities were shown in Tab. 1, 2 and 3. Financial views on dairy cows are given by Tab. 4.

Simulating the fate of dairy cows from herds and dairy cows after surgery allows us to financially express the differences in their lifetime generated incomes and costs. Each cow from cowshed with 1000 cows was simulated using Arena software.

\subsection{Description of individual simulation steps}

This subchapter describes the individual steps of the simulation, which are then drawn in the diagram in Fig. 1.

- Create a cow. Include a cost of 30,000 CZK for the purchase and $500 \mathrm{CZK}$ for the first insemination (the pregnant heifer is acquired in the 7th month of pregnancy, the gestation period is 285 days).

○ Every day:

- If costs are calculated (lactation cycle $\geq 1$ or insemination was successful):

- Include the cost of 155 CZK per daily ration (During the first lactation, only $285-7 * 30.5$ days are counted).

- If the date of the next insemination has occurred (more than 50 days after calving) and is Thursday:

- Inseminate a cow with a probability of success of 1 /insemination index, the result of insemination will be tested in 30 days.

- Include the cost of insemination 500 CZK.

- If the test date for the insemination result has occurred and is Monday:

- If the insemination was successful:

- $\quad$ Set the day of birth of the calf = day of the last insemination +285

- If insemination was not successful:

- If the maximum number of inseminations has been exceeded:

- $\quad$ Discard the cow - end of simulation.

- Else:

- $\quad$ Day of next insemination $=$ day +9 .

- If a calf is born:

- Increment the lactation cycle.

- Count the profit of 3,000 CZK for the calf.

- $\quad$ Feed test day $=$ day $+30 \times i, i=1, \ldots, 170$.

- The cow will develop LDA with a probability of $3 \%$, the day of the disease $=$ day + $\operatorname{LOGN}(2.398,0.367)$.

- If it is possible to milk a cow (it is in the lactating cycle and there are more than 50 days left until the birth of the calf)

- Calculate milk (according to the condition diseased/healthy, according to the lactation cycle).

- $\quad$ count the profit from the milk $=8.57$ * weight of milked milk according to group and number 
of lactation cycle from Tab 1.

- If the cow is sick and the day has come for the disease to manifest:

- Include the cost of 4,500 CZK per surgery.

- $\quad$ with probability of:

- $\quad 8.4 \%$ the cow will die within 30 days. Costs $5000 \mathrm{CZK}$, end of simulation.

- $\quad 9 \%$ the cow will survive 30 to 305 days. Gain 13800 CZK, end of simulation.

\section{- $\quad$ Rest: survives.}

- If no further insemination has been performed and with a probability of $66.6 \%$ :

- Delay the day of the next insemination by 20 days.

- If the limit of the number of lactation cycles (according to the parameter) has been reached:

- Count the profit of 15000 CZK (sale of a cow for meat). Discard the cow, end of the simulation.

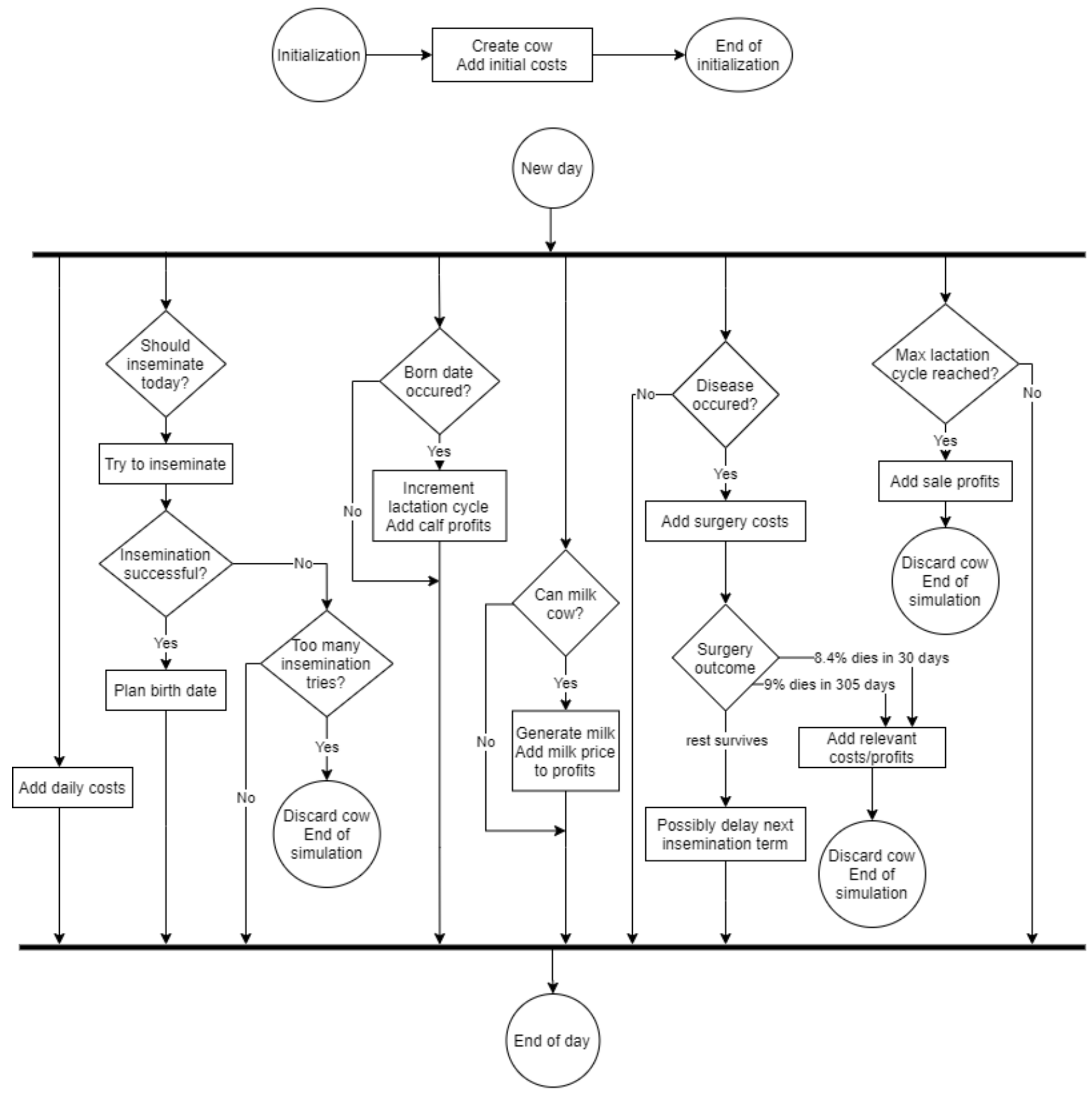

Figure 1. A diagram of the simulation. 


\section{Simulation and results}

Based on the presented simulation model, the impact of the choice of the parameter of the maximum number of cow inseminations within one lactation cycle was investigated. The parameter values were set in the range from 2 to 9. The result of the simulation shows that the highest gain is achieved with the maximum number of inseminations. But results for values $6-9$ are very similar. See fig. 2.

The hazard function can also be interesting. The hazard function is defined as the event rate at time $t$ conditional on survival until time $t$ or later. In the Fig. 3 we can see the hazard function, which describes the survival of cows according to the maximum number of inseminations. The average number of the last surviving lactation cycles according to the maximum number of inseminations can then be seen in the table 5 . From table 5 , it is obvious that at least 5 inseminations are needed to maintain breeding without the purchase of heifers.

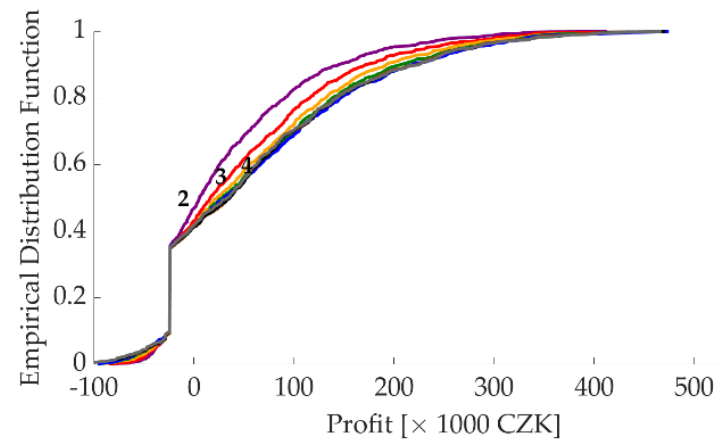

Figure 2a. Dependence of gain on the maximum number of inseminations.

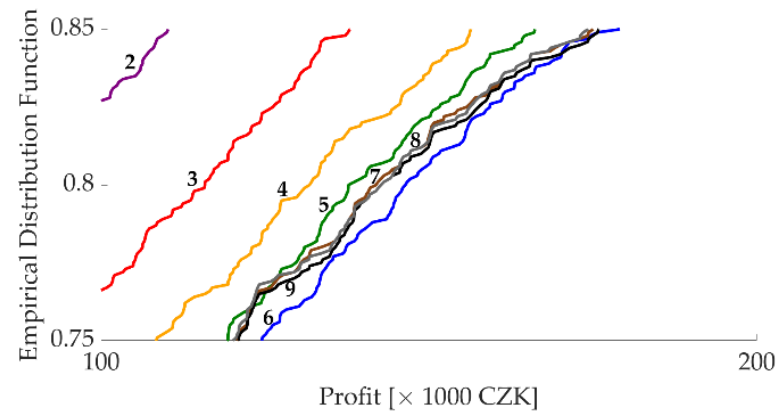

Figure $\mathbf{2 b}$. Zoomed figure $2 \mathrm{a}$.

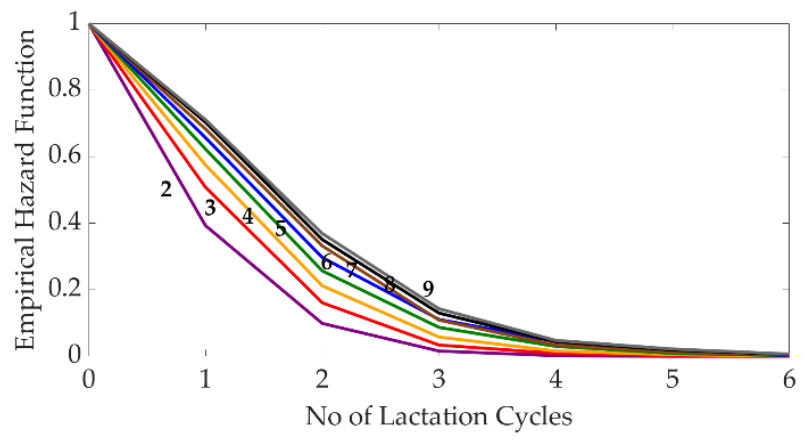

Figure 3. Hazard functions for different maximum number of inseminations.

In table 5 and 6 , for different maximal number of inseminations survival statistics are presented. In table 7, for different maximal number of inseminations profitability statistics are presented.

Table 5. Average number of the last surviving lactation cycle according to the maximum number of inseminations.

\begin{tabular}{ll}
\hline $\begin{array}{l}\text { Maximum } \\
\text { number of } \\
\text { inseminatio } \\
\text { ns }\end{array}$ & $\begin{array}{l}\text { Average number of last } \\
\text { surviving lactation } \\
\text { cycle }\end{array}$ \\
\hline 2 & 1.510 \\
3 & 1.714 \\
4 & 1.868 \\
5 & 2.009 \\
6 & 2.127 \\
7 & 2.177 \\
8 & 2.257 \\
9 & 2.304 \\
\hline
\end{tabular}

Source own

Table 6. Dependence of the maximum number of inseminations on the number of surviving cows at the end of lactation.

Percentage of surviving cows at the end of the lactation 1 to

\begin{tabular}{cllllll}
$\begin{array}{l}\text { Maximum } \\
\text { number of } \\
\text { inseminations }\end{array}$ & 1 & 2 & 3 & 4 & 5 & 6 \\
\hline 2 & 60.7 & 29.4 & 8.3 & 1.4 & 0.2 & 0.0 \\
3 & 49.2 & 34.7 & 12.7 & 2.5 & 0.7 & 0.2 \\
4 & 42.5 & 36.3 & 15.4 & 4.2 & 1.1 & 0.5 \\
5 & 37.7 & 36.6 & 17.0 & 5.7 & 2.1 & 0.9 \\
6 & 34.3 & 36.0 & 18.6 & 6.6 & 3.2 & 1.3 \\
7 & 31.7 & 35.1 & 22.3 & 7.5 & 2.1 & 1.3 \\
8 & 29.7 & 35.2 & 22.1 & 8.6 & 2.5 & 1.9 \\
9 & 28.9 & 24.2 & 22.6 & 9.5 & 2.6 & 2.2 \\
\hline
\end{tabular}

Source own. 
Table 7. Gain according to the maximum number of inseminations.

\begin{tabular}{lll}
\hline $\begin{array}{l}\text { Maximum } \\
\text { number of } \\
\text { inseminatio } \\
\text { ns }\end{array}$ & Median [CZK] & Mean [CZK] \\
\hline 2 & 5703 & 34370 \\
3 & 16460 & 47467 \\
4 & 23308 & 55187 \\
5 & 28408 & 59744 \\
6 & 30218 & 62840 \\
7 & 35910 & 61548 \\
8 & 36192 & 61902 \\
9 & 32672 & 60913 \\
\hline
\end{tabular}

Source own.

The objective of our research was to develop a simulation model to estimate the economic lifetime profit of a dairy cow in a cowshed. Special attention was paid to LDA disease. Cows with this disease are more excluded from breeding, have a smaller total 305$\mathrm{d}$ yield, have a longer interval between calving and, as a result, higher feed costs. In the case of the cow with LDA disease, the result of the surgery is simulated. The surgery is usually successful with a probability of $91.6 \%$.

The date of insemination is determined, for cows after surgery the date is shifted compared to the 1 st group by 20 days. If the disease manifested itself early and the surgery was performed well in advance of the planned date of insemination, the insemination was performed in due time. The input variable maximum number of insemination attempts for each cow is smaller or equal to 9 . After the last unsuccessful insemination attempt, the cow is excluded.

Table 8a. Gains of healthy cows (group 1) compared to cows diagnosed with LDA (group 2) for maximum number of inseminations equals to 6 .

\begin{tabular}{ccccc}
\hline $\begin{array}{l}\text { Max. } \\
\text { lactation } \\
\text { cycle }\end{array}$ & $\begin{array}{c}\text { Group 1- } \\
\text { avg. milk yield } \\
{[\mathrm{kg}]}\end{array}$ & $\begin{array}{c}\text { Group 2- } \\
\text { avg. milk yield } \\
{[\mathrm{kg}]}\end{array}$ & $\begin{array}{c}\text { Group 1- } \\
\text { avg. profit } \\
{[\text { CZK] }}\end{array}$ & $\begin{array}{c}\text { Group 2- } \\
\text { avg. profit } \\
{[\text { [CZ] }}\end{array}$ \\
\hline 1 & 3286 & 2828 & -6780 & -24121 \\
2 & 19537 & 18034 & 70701 & 61502 \\
3 & 31631 & 25024 & 116104 & 51949 \\
4 & 45236 & 41958 & 163305 & 128749 \\
5 & 54747 & 40755 & 181255 & 57524 \\
6 & 70591 & 0 & 245662 & 0 \\
7 & 83545 & 64033 & 274124 & 166152 \\
8 & 0 & 84300 & 0 & 249883 \\
\hline
\end{tabular}

Source own.

Table 8b. Percentage of individual groups from tab. 8 a in the group of sick and healthy cows. Percentage of individual groups from tab. $8 \mathrm{a}$ in the whole herd.

\begin{tabular}{ccc}
$\begin{array}{l}\text { Max. lactation } \\
\text { cycle }\end{array}$ & Group 1 & Group 2 \\
\hline 1 & $34.6(32.8)$ & $28.3(1.5)$ \\
2 & $36.2(34.3)$ & $32.1(1.7)$ \\
3 & $18.7(17.7)$ & $17.0(0.9)$ \\
4 & $6.2(5.9)$ & $13.2(0.7)$ \\
5 & $3.1(2.9)$ & $5.7(0.3)$ \\
6 & $1.1(1.0)$ & $0(0)$ \\
7 & $0.1(0.1)$ & $1.9(0.1)$ \\
8 & $0(0)$ & $1.9(0.1)$ \\
\hline$\Sigma$ & $100(94.7)$ & $100(5.3)$ \\
\hline
\end{tabular}

Source own.
Finally, the simulated data are ready to be examined from a financial point of view. During the simulation, we monitor the financial income and costs of the dairy cow separately for each of her lactations. For dairy cows after surgery, the cost of the surgery is $4500 \mathrm{CZK}$.

Table 8 shows the difference in gains of healthy cows compared to cows diagnosed with LDA in the respective lactation cycle.

The estimated difference between the averages of the profits of both groups is $13736 \mathrm{CZK}$.

\section{References}

Bekara, M.E., Bareille, N. (2019). Quantification by simulation of the effect of herd management practices and cow fertility on the reproductive and economic performance of Holstein dairy herds.Journal of Dairy Science, 102(10):9435-9457.

Calsamiglia, S., Astiz, S., Baucells, J., Castillejos, L. (2018). A stochastic dynamic model of a dairy farm to evaluate the technical and economic performance under different scenarios. Journal of Dairy Science, 101(8):7517-7530.

Congleton, W.R., JR. (1983) Dynamic model for Combined Simulation of Dairy Management Strategies. Journal of Dairy Science, 67:644-680.

Dooley, A.E., Smeaton, D., McDermott, A. (2020). A model of the New Zealand beef value chain. In: Zerger, A. and Argent, R.M. (eds.) MODSIM 2005 - International Congress on Modelling and Simulation: Advances and Applications for Management and Decision Making, 12 Dec 2005 - 15 Dec 2005. Melbourne, Australia: Modelling and Simulation Society of Australia and New Zealand, pp. 190-195. ISBN: 0-9758400-2-9.

Hawkins, A., Burdine, K., Amaral-Phillips, D., Costa, J.H.C. (2019). An economic analysis of the costs associated with pre-weaning management strategies for dairy heifers. Animals, 9(7):No471.

Haloun, T., Marek, J., Rajmon, R., Kršíková, M. (2016). Analysis in a time series of milk-yield production. In: Mathematical Methods in Economics 2016 (MME 2016). Liberec: Technická univerzita v Liberci. 2016. pp. 248-253. ISBN 978-80-7494-296-9.

Hamann, H., Wolf, V., Scholz, H., Distl, O. (2004). Relationships between lactational incidence of displaced abomasum and milk production traits in German Holstein cows. J. Vet. Med. A., 51: 203-208.

Jorritsma, R, Westerlaan, B, Bierma, M., P, Frankena, K. (2008). Milk yield and survival of Holstein-Friesian dairy cattle after laparoscopic correction of left-displaced abomasum. Vet Rec., 162(23):743-6.

Louda, F. (2008). Ukazatele zabřezávání. In: Uplatnění biologických zásad při řízení reprodukce plemenic. pp. 26 - 27., Výzkumný ústav pro chov skotu s. r. o.

Kariuki, C.M., van Arendonk, J.A.M., Kahi, A.K., Komen, H. (2019).Deterministic simulations to determine the impacts of economic and non-economic breeding objectives on sustainable intensification of developing smallholder dairy farms. Livestock Science, 226:7-12.

Kelton, W.D., Randal, P., Sadowski, R., Zupick, N. B. (2015). Simulation with Arena. Sixth edition. New York, N.Y: McGrawHill Education. 
Kikuhara, K., Kumagai, H., Hirooka, H. (2009). Development and Evaluation of a Simulation Model for Dairy Cattle Production System Ingrated with Forage Crop Prediction. Asian-Aust. J. Anim. Sci., 22(1):57-71.

Kikuhara, K., Hirooka, H. (2009). Application of a Simulation Model for Dairy Cattle Production Systems Integrated with Forage Crop Production: the Effects of Whole Crop Rice Silage Utilization on Nutrient Balances and Profitability. Asian-Aust. J. Anim. Sci., 22(2):216-224.

Marek, J., Rajmon, R., Haloun, T. (2015). Critical evaluation of seven lactation curve estimation models. In: Abraham Ajith, Jiang Xin Hua, Snášel Václav, Pan Jeng-Shyang (eds.). Intelligent Data Analysis and Applications. Proceedings of the Second EuroChina Conference on Intelligent Data Analysis and Applications, ECC 2015. New York: Springer International Publishing, pp. 7384. ISBN: 978-3-319-21206-7

Marek, J. (2016). Various models for fitting of lactation curve and its curvatures.In: Bod'a, M. (eds.). 5th International Scientific Conference FERNSTAT 2016, 22 Sep 2016-23 Sep 2016. BanskaBystrica, Slovakia: Slovak Statistical and Demographic Society, pp. 72-83. ISBN 978-80-88946-74-8. ISSN 2453-9856.

Mur-Novales, R., Lopez-Gatius, F., Fricke, P. M., Cabrera, V.E. (2018). An economic evaluation of management strategies to mitigate the negative effect of twinning in dairy herds. Journal of Dairy Science, 101(5):8335-8349.

Pérez-Méndez, J.A., Roibás, D., Wall, A. (2020). Somatic cell counts, reproduction indicators, and technical efficiency in milk production: A stochastic frontier analysis for Spanish dairy farms. Journal of Dairy Science, 103(8):7141-7154.

Shaver, R. (1997). Nutritional risk factors in the etiology of left displaced abomasum in dairy cows: a review. J. Dairy Sci. 80(10):2449-2453.

Stewart, W. J. (2009). Probability, Markov chains, queues, and simulation: the mathematical basis of performance modeling. Princeton, Princeton University Press. 